УДК 343:9.01

DOI https://doi.org/10.32850/sulj.2019.4.3.12

\title{
ПРОБЛЕМА ПРОТИДІЇ ПРОВОКАЦІЇ В ОПЕРАТИВНО-РОЗШУКОВІЙ ДІЯЛЬНОСТІ
}

Папуша I. 0.

У статті розглядається проблема дієвості і законності методів оперативно-розшукової діяльності в контексті реформування кримінально-процесуального законодавства України. Потреба протистояти злочинному середовищу зумовлює соціальну необхідність, корисність і моральність використання таємних, негласних методів. Саме завдяки їм розкривається та розслідується понад $85 \%$ тяжких та особливо тяжких злочинів, вирішуються завдання кримінального провадження. Розглянуті у статmі питання дозволили дійти висновку про наявність прогалин у кримінальному, оперативно-розшуковому та кримінально-процесуальному законодавстві. Передусім дискусійним залишається питання декриміналізації діяння, чи, натомість, розширення застосування діючої правової норми, межі спонукання до злочину, відповідь на яке дасть змогу вдосконалити наявний правовий арсенал правоохоронної діяльності.

Ключові слова: оперативно-розшукова діяльність, злочинність, негласні слідчі (розшукові) дії, превенція, провокація.

В статье рассматривается проблема действенности и законности методов оперативно-розыскной деятельности в контексте реформирования уголовно-процессуального законодательства Украины. Потребность противостоять преступной среде обусловливает социальную необходимость, полезность и нравственность использования тайных, негласных методов. Именно благодаря им раскрывается и расследуется более $85 \%$ тяжких и особо тяжких преступлений, решаются задачи уголовного производства. Рассмотренные в статье вопросы позволили сделать вывод о наличии пробелов в уголовном, уголовно-процессуальном законодательстве и в оперативно-розыскной деятельности. Прежде всего, дискуссионным остается вопрос декриминализации деяния, или, вместо того, расширение применения действующей правовой нормы, границы побуждения к преступлению, ответ на который позволит совершенствования имеющегося правового арсенала правоохранительной деятельности.

Ключевые слова: оперативно-розыскная деятельность, преступность, негласные следственные (розыскные) действия, превенция, провокация.

One of the most important arrivals of power on an everyday basis is the struggle against evil, and the unequal mental efficiency is the acquisition of knowledge about the preparation, performance, commitment of the grave and especially difficult reasons. You have the right to protect the law of the organization of special forms and methods, which are not obstructed by the sovereign organs of power and administration. However, it's not very easy to stink at the service interests and indicators of openness, who themselves violate the rights of people, and the activity is tied to fighting and the factories, actually, the whole thing is clear of the times. The article deals with the problem of the effectiveness and legality of the methods of operational-search activity in the context of reforming the criminal-procedural legislation of Ukraine. The need to confront the criminal environment determines the social need, usefulness and morality of using secret, unspoken methods. It is thanks to them that more than $85 \%$ of serious and especially serious crimes are revealed and investigated, and the tasks of criminal proceedings are solved. The issues considered in the article allowed to conclude that there are gaps in the criminal, operational-search and criminal procedure legislation.

Otsinuyuchi materials, rejected by operational-rozshukovymi bodies, judge the Victory Law on the ARD in the dzherel dzherela procedural law. Odnak, oskilki tsi vidomodosti obsessed with an unprincipled gentry, they do not vidpovidayut criteria for admissibility of evidence. The main thing here is to emphasize the importance of maintaining the position of the Constitution of Ukraine, which is most likely to enjoy social welfare, honor and good health, lack of fitness. Rights and freedoms of people, guaranties to be held in place and rights of the state. Vidpovidno until part 3 of article 62 of the Constitution of Ukraine sums up to bring to blame individuals to mumble on the basis of $\mathrm{cmb}$ i. Legally, on these ambushes base and operational-roshshukova diyalist. By his drawer, the Constitutional Court of Ukraine, his decision No. 12-rp / 2011 rok wid 20 july 2011 b. dyalnosti reassured by those especially without the necessary constitutional provisions, but in order to be ruined by the order established by law, as well as by having a whip to restore the law and order, if necessary, ovazhenoï on zdiysnennya takoi diyalnosti individuals.

First of all, the question of decriminalization of the act, the expansion of the application of the current legal norm, the boundaries of the incitement to crime, the answer to which will improve the legal arsenal of law enforcement, remains debatable.

Key words: operative-search activity, crime, secret investigative (search) actions, prevention, provocation.

Постановка проблеми та іï актуальність. Одним із важливих завдань держави на сучасному етапі $\epsilon$ боротьба зі злочинністю, а неодмінною умовою іiі ефективності - одержання відомостей про підготовку, вчинення, приховування слідів тяжких та особливо тяжких злочинів, а також злочинів, які вчинені кваліфікованим способом чи мають замаскований характер. У цій боротьбі правоохоронні органи використовують спеціальні форми і методи, що не застосовуються іншими державними органами влади і управління. Однак нерідко вони настільки захоплюються службовими інтересами і показниками розкриття, що самі порушують права людини, а діяльність, спрямована на боротьбу зі злочинами, фактично продукує злочинну поведінку, що втілюється в суспільно небезпечному діянні, яке одразу ж припиняють і розкривають [1, с. 3].

Аналіз останніх досліджень і публікацій. Різні аспекти проблеми провокації з боку уповноважених осіб правоохоронних органів під час проведення такої негласної (розшукової) дії вже знайшли своє висвітлення у працях І. Басецького, В. Бобрового, А. Возного, Н. Ярмиш, Д. Гребельського, А. Лєкара, В. Грохольського, Є. Дідоренка, І. Козаченка, І. Сер- 
вецького, М. Багрія, О. Білічака, Д. Сергєєвої, О. Дроздова, С. Кудінова, Р. Шехавцова, В. Уварова, В. Динту, С. Фоміна та інших.

Разом з тим правові механізми, спрямовані на недопущення провокації злочину, як складова частина принципу законності в оперативно-розшуковій діяльності та під час проведення негласних слідчих (розшукових) все ще потребують деталізації.

Мета статті - розглянути проблему дієвості і законності методів оперативно-розшукової діяльності в контексті реформування кримінально-процесуального законодавства України.

Виклад основного матеріалу. Потреба протистояти злочинному середовищу зумовлює соціальну необхідність, корисність і моральність використання таємних, негласних методів. Саме завдяки їм розкривається та розслідується понад 85\% тяжких та особливо тяжких злочинів, вирішуються завдання кримінального провадження [2, с. 33]. Водночас основна маса громадян країни зовсім не розуміє сутність роботи правоохоронців, що породжує появу різноманітних стереотипів, несприятливих для правоохоронців, оскільки більшості притаманний острах невідомих або незрозумілих явищ, до яких належить і прихована від очей звичайних людей оперативно-розшукова діяльність. Одні вважають іiі необхідною для розкриття злочинів, інші категорично заперечують. І якраз можливість використання провокативних прийомів і продукує таке негативне до неї ставлення. Врешті, й судова практика засвідчує наявність проблеми. Якщо судами західних країн результати більшості негласних засобів досудового розслідування визнаються судовими доказами (у США, наприклад, до 95\%), то в Україні, протягом перших 3-х років застосування норм чинного КПК України їх частка становила лише $5 \%$ [2, с. $33 ; 3$, с. $155-156 ; 4 ; 5$, с. 248].

Історичні корені провокації як правового явища походять $з$ часів античності. Зокрема, Соломоном були запроваджені спеціально уповноважені правоохоронці - сікофанти, котрі згодом, вдаючись до провокацій, істотно ускладнили суспільне життя [6, с. 87]. Сам же термін походить із Древнього Риму, якими встановлювалося правило “provocatio ad populum” - процедура прямої апеляції до народу засудженого громадянина. Тобто правовий інститут провокації споконвічно розумівся дещо інакше порівняно із сучасним його змістом. А вже в епоху середньовіччя, коли створювалася політика, яка брала до уваги тільки реальні інтереси монарха, відбувається поступова еволюція поняття. 3 середини XIX ст. розпочалась наукова розробка провокації, доцільності й правомірності їі застосування. Німецький криміналіст Брейденбах трактував їі у звичному контексті виявлення і усунення потенційно небезпечних для уряду кіл, розправи з ними неправовими методами, за допомогою створення надзвичайної обстановки. Своєю чергою російський правоохоронець, сумнозвісний І. Ліпранді, теоретично обґрунтував іï введення до арсеналу оперативно-розшукових заходів. У тому числі й під час розслідування посадових злочинів [7, с. $114 ; 8$, с. 24-28].

Провокація цілком і повністю базувалась на діяльності агентури. Чітке дотримання норм закону прирікало ï на роль пасивних спостерігачів, істотно зменшуючи інформаційні можливості. I навпаки, чим активніше агент займався протиправною діяльністю, тим більшу цінність він становив. Перехід тонкої грані від агентурної роботи як найефективнішого методу до провокації залежав від сумлінності та професійної майстерності оперативного співробітника. Врешті, серед широкого загалу провокаторами стали називати усіх без винятку таємних співробітників. А оперативно-розшукова діяльність була повністю дискредитована не лише в очах пересічних громадян, але й дипломатів [9, с. 465-479; 10, с. 26].

Розвитку запобігання провокації набуло в радянський період, напрацювання якого були творчо використані і в перші роки державної незалежності України. Водночас, з огляду на вдосконалення чинної правоохоронної системи та зумовлену цим перебудову кримінального та процесуального законодавства, ми зустрілись із штучним звуженням законодавцем проблеми до провокації хабара (ст. 370 КК України) [2, с. 37]. Слід визнати, що чіткого поняття та ознак провокації ця стаття не містить. У диспозиції зазначається лише «свідоме створення службовою особою обставин і умов, що зумовлюють пропонування хабара» службовій особі іншою особою.

Певним бар'єром на шляху провокації був також прокурорський контроль, адже той «зобов' язаний викласти обставини, які свідчать про відсутність під час негласної слідчої (розшукової) дії провокування особи на вчинення злочину». На його доцільність вказують дані О. Баганця, котрий зазначав, що подекуди правоохоронці навіть стали використовувати своєрідних кадрових хабародавців, провокуючи і викриваючи такого виду злочини. Звичайно суди, викриваючи такі факти, не сприймали здобуті таким шляхом докази і виправдовували подібних підсудних або повертали справи на додаткове розслідування (до прийняття нового КПК України 2012 року) [11; 12].

Разом з тим є протилежна думка, що якщо виходити з диспозиції статті, то практично будь-які оперативно-розшукові заходи, спрямовані на документування хабарництва, $є$ провокацією. Такий погляд спростовується ст. 6 Закону України «Про оперативно-розшукову діяльність» від 18 лютого 1992 року № 2135-XII. Таку позицію приймають і оперативні працівники [13].

Зрозуміло, що з огляду на необхідність посилення боротьби із корупцією тонка грань між провокацією та оперативною комбінацією потребувала усунення прогалин у законодавстві. Мали місце навіть пропозиції доповнення ст. 370 частиною, що передбачала звільнення від кримінальної відповідальності осіб, які відповідно до закону виконують спеціальне завдання, доповнити чинний КК України новою статтею «Передача хабара службовій особі без їі згоди» та надати оперативним працівникам права здійснення провокації хабара. Таким чином, ті не лише отримали право безкарно здійснювати провокацію, мала місце також загроза штучного створення доказів обвинувачення. Причому користь таких дій була більш ніж сумнівною, адже більшість хабарників мають роками налагоджені схеми отримання або давання хабарів або діють через посередників [14].

Але вже після Революції гідності вищі посадові особи нашої держави, політики і навіть Президент України стали ініціювати узаконення провокації підкупу. Слід зауважити, що такі ініціативи мають широку громадську підтримку. Згідно з результатами опитування, проведеного в грудні 2017 року фондом «Демократичні ініціативи» і Центром Разумкова, 54\% громадян визнали 
провокування хабара прийнятним і вважають доцільним легалізувати його у законодавстві. Навіть більще, 56\% опитаних прокурорів, 65\% слідчих та $72 \%$ оперативних працівників вважають за доцільне розширення меж застосування провокації у правоохоронній діяльності в цілому [15; 2, с. 40; 16].

Деякі вчені також висловлюють міркування щодо можливості декриміналізації відповідальності за провокацію хабара. Ще у 2002 р. про це писав А. АльФаїз, зазначаючи про нефункціонування такої правової норми, а О. Мороз ототожнював з провокацією саму оперативно-розшукову діяльність [13]. Загалом такі висловлювання вказують не стільки на необхідність декриміналізації цього діяння, скільки на важливість встановлення критеріїв відмежування провокаційної діяльності від законної оперативно-розшукової.

Певною мірою такі заклики вже узаконені, будучи відображеними у «Державній програмі щодо реалізації засад державної антикорупційної політики в Україні на 2015-2017 роки» та «Засадах державної антикорупційної політики в Україні на 2014-2017 роки». У розділі «Створення доброчесної публічної служби» відверто йдеться про допустимість «провокації надання неправомірної вигоди», хоча й виключалась можливість іï підстави для початку кримінального провадження. Містяться там і рекомендації стосовно інституціалізації провокації та провокаторів $[16 ; 17 ; 18]$. Та враховуючи те, що відповідний Закон щодо порядку здійснення таких заходів (хоча про його необхідність і йшлося) прийнятий не був, боротьба з хабарництвом у площину превенції так i не перейшла, натомість звівшись до кримінального переслідування окремого посадовця-хабарника, провокування схильних до одержання хабара держслужбовців і звільнення тих, що піддалися провокації.

Загалом боротьба з корупцією звелась здебільшого до скандалів, протиборства між НАБУ, ГПУ та СБУ, відомого як «війна антикорупціонерів». Усе це ще більше актуалізувало питання правомірності викриття злочинів за допомогою осіб, які працюють під прикриттям. При тому, що викладені в «Інтернет» матеріали спростовують підозри у провокації [12; 19].

Водночас працівники НАБУ наголошували на тісній взаємодії із співробітниками спецслужб США, зокрема ФБР. Зауважимо, що в США та ЄС провокація значною мірою узаконена. Тож у ГПУ пролунали обвинувачення з боку Європейської служби зовнішніх дій, Держдепу США та інших структур.

Фактично підставою для скандалу стала активна участь у справі оперативників правоохоронних органів, що, окрім іншого, суперечить практиці Європейського суду з прав людини (ЄСПЛ), котрий категорично відкидає можливість активних дій правоохоронців. Водночас ситуація $\epsilon$ складнішою, і сам лише факт участі у передачі підозрюваному грошей негласним агентом НАБУ не свідчить ані про провокацію, ані про наявність ознак злочину, передбаченого ст. 370 КК України.

Стосовно таких дій М.І. Мельник вважає, що від провокації хабара слід відрізняти правомірні дії, що вживаються для викриття хабарників. В.В. Кузнецов та А.В. Савченко також відзначають, що правомірні дії, що вживаються для викриття, не є провокацією. Навпаки, під час провокації злочинець сам викликає в інших намір вчинити злочин з метою його викриття [13].
Певною мірою підтвердження таких дій можна знайти у статтях 246 і 272 КПК, де чітко визначені підстави проведення негласних слідчих (розшукових) дій, та у ст. 8 закону «Про оперативно-розшукову діяльність». Водночас ряд фахівців наголошують на винятковій прерогативі прокурора, що має право прийняти рішення про проведення такої негласної слідчої (розшукової) дії, як контроль за вчиненням злочину [13].

Також сьогодні у кримінально-правовій кваліфікації злочинів наявні певні проблеми відмежування провокації підкупу від суміжних діянь, у тому числі у зв'язку із внесенням КК України у цій сфері суттєвих змін. Так, О. Грудзуром обґрунтовано, що провокація підкупу не виключає кримінальної відповідальності за його давання чи одержання (ст. 368 та 369 КК України). Утім, якщо вона поєднується із вимаганням або зумовлює його, то хабародавець звільняється від кримінальної відповідальності. Натомість діяння одержувача кваліфікують за ч. 2 ст. 368 КК України, а у разі, коли він особисто вчиняє провокацію, ще й за ч. 1 або 2 ст. 370 КК України [13].

Поряд із цим давання та одержання, вчинені під час провокації, не завжди $є$ закінченими злочинами, оскільки мета провокації (викриття) досягається раніше, ніж службова особа одержує хабар - підкуп. У такому разі його давання та одержання повинні кваліфікуватися із посиланням на ч. 2 або 3 ст. 15 КК України як замах на вчинення злочину. Якщо з провокаційною метою службова особа організувала давання чи одержання підкупу, підбурила або сприяла у цьому, іiі дії слід розцінювати як співучасть і додатково кваліфікувати за відповідними частинами статей КК України [13].

Але провокаційна діяльність можлива щодо будьякого умисного злочину. Отже, законодавець невиправдано звузив суб'єктів провокації, визначаючи такими лише службових осіб. Часто словосполучення «виявлення кримінальних правопорушень» сприймається як обов'язок виявити їх якнайбільше і якомога швидше. На практиці існує уже добре відпрацьований механізм провокації вчинення злочинів, передбачених статтями 305-309, 311, 321, 368-369 тощо. КК України і злочинні дії правоохоронців залишаються латентними. Особливо В процесі такої НСРД, як контроль за вчиненням злочину (ст. 271 КПК України), та під час проведення таких OP3, як контрольована поставка, контрольована та оперативна закупка. Така ситуація часто призводить до того, що, незважаючи на ефективність оперативно-розшукових засобів попередження та розкриття злочинів, ї результати втрачають своє доказове значення у кримінальній справі [20; 2, с. 40; 21, с. 253; 22; 23].

Оцінюючи матеріали, отримані оперативно-розшуковими органами, суди використовують Закон про ОРД як джерело процесуального права. Однак, оскільки ці відомості одержано непроцесуальним шляхом, вони не відповідають критеріям допустимості доказів. Головною обставиною тут слід вважати відповідність усіх чинних чи запропонованих положень Конституції України, котра найвищою соціальною цінністю проголошує життя i здоров'я, честь і гідність, недоторканність i безпеку особи. Права і свободи людини, їх гарантії складають зміст і цілі державної діяльності. Відповідно до ч. 3 ст. 62 Конституції України усі сумніви щодо доведеності вини особи тлумачаться на їі користь. Закономірно, що на цих засадах базується і оператив- 
но-розшукова діяльність. Своєю чергою Конституційний суд України своїм рішенням № 12-рп/2011 року від 20 жовтня 2011 р., винесеному у справі за конституційним поданням СБ України, вказав, що обвинувачення у вчиненні злочину не може ґрунтуватися на фактичних даних, одержаних в результаті оперативно-розшукової діяльності уповноваженою на те особою без дотримання конституційних положень або з порушення порядку, встановленого законом, а також одержаних шляхом вчинення цілеспрямованих дій щодо їх збирання і фіксації із застосуванням заходів, передбачених Законом, не уповноваженою на здійснення такої діяльності особою [24, с. $129 ; 25$, с. 37-38; 22].

Окрім того, частина 2 статті 8 КПК, статті 17 Закону України «Про визнання рішень та застосування практики Європейського суду з прав людини» як джерела права проголошують Конвенцію про захист прав людини та основних свобод та практику Європейського Суду з прав людини. Відповідно до цього наслідки протиправного спонукання особи до вчинення нею злочину можна розглядати як істотне обмеження прав та свобод людини і громадянина, гарантованих національним та міжнародним законодавством. Як наслідок, недопустимими визнаються фактичні дані, одержані внаслідок проведення відповідних негласних заходів як доказів для використання в конкретному кримінальному провадженні та прийняття процесуальних рішень [26, с. 93].

У зв'язку з цим теорія зайнялася пошуком шляхів перетворення в докази відомостей, отриманих оперативним шляхом. Було висловлено думку, що доказами $\epsilon$ не самі по собі оперативні дані, а отримані на їх основі або з їхньою допомогою відомості, укладені в процесуальну форму.

Як приклад можна згадати виправдальний вирок Лубенського міськрайонного суду Полтавської області по справі № 539/741/16-к від 22.03.2018 р. У процесі судового розгляду було зроблено висновок, що перебіг подій, обстановку злочину було ретельно розроблено та підготовлено співробітниками СБУ, а також залученими ними особами. Варто, однак, зауважити, що в подальшому ухвалою апеляційного суду Полтавської області було відкрито апеляційне провадження на вирок за скаргою прокурора Лубенської місцевої прокуратури, а отже, однозначно стверджувати про остаточність встановлення факту провокації у даній справі наразі неможливо [26, с. 93].

Загалом саме стосовно органів державної безпеки, з огляду на специфіку їхньої діяльності, підозри у провокації озвучуються найчастіше. Достатньо згадати хоча 6 нашумілу «справу Бабченка». Врешті, до арсеналу спецслужб входять такі поширені у них методи роботи, як підстава, агентурна комбінація, оперативний експеримент тощо, котрі у разі неправильного проведення можуть перейти у провокацію. Наприклад, під час здійснення контррозвідувальної діяльності вони ведуть боротьбу із зловживанням дипломатичним імунітетом. А у разі спроби форсувати події це набуває ознак провокації. Передчасна ж підстава скидається на фабрикацію злочинної діяльності. В радянські часи такі дії мотивувались інститутом крайньої необхідності, особливих обставин. Доволі аргументовано крайньою необхідністю проведення оперативно-розшукових заходів щодо найбільш небезпечних проявів злочинності мотивує і М. Корнієнко. Інші сучасні правознавці вважають, що відмінною рисою провокації $є$ здійснення певних активних дій у ситуації, коли не було достатніх підстав вважати, що злочин був би вчинений без провокаційних дій $[27$, с. $13-46 ; 28$, с. 125; 29]. Так, О.І. Альошина не погоджується з думкою про можливість виправдання окремих випадків провокації злочинів крайньою необхідністю. По-перше, тут немає безпосередньої загрози заподіяння шкоди - першого елементу підстави крайньої необхідності. По-друге, тут виключається й другий елемент підстави крайньої необхідності - відсутність реальної можливості усунути небезпеку, іншими засобами, ніж вчиненням провокаційних дій, адже до поведінки провокатора у особи, яка провокується, ще має бути відсутній намір вчинити певний злочин. Таким чином, саме провокатор, по суті, виступає особою, яка породжує злочинця та злочин [30, с. 12].

На нашу думку, діяльність оперативно-розшукових підрозділів має бути адекватною характеру та ступеню суспільної небезпеки злочинного посягання. Вона повинна відповідати співвідношенню законності та гласності, конспіративності й відкритості, тотальності оперативних заходів й індивідуальності підходу до тієї чи іншої оперативної ситуації. Тому оперативні підрозділи повинні мати законні приводи для початку ОРД. Мають приділяти особливу увагу обґрунтованості підстав для їх проведення.

Під час порівняння змісту глави 21 КПК України та ст. 8 Закону України «Про оперативно-розшукову діяльність» одразу стає зрозумілою суть реформи, проведеної у 2012 році. В кримінальному процесі повністю виключено етап дослідчої перевірки інформації про злочин, в тому числі шляхом проведення оперативно-розшукових заходів. Відтепер всі гласні та негласні слідчі (розшукові) дії можуть вчинятися винятково в межах кримінального провадження, внесеного в Єдиний реєстр досудових розслідувань (ЄРДР). Хоча не обійшлося без колізій.

Із введенням у вітчизняний кримінальний процес інституту НСРД результати ОРД як докази майже не використовуються, що негативно впливає на досягнення мети та вирішення завдань кримінального провадження. Окрім цього, значна кількість результатів НСРД та ОРД не використовується ще й тому, що не містить доказової інформації, засвідчуючи безпідставність їх проведення, а окремі результати не визнаються доказами у суді [2, с. 34].

Таким чином, з одного боку, Закон про ОРД явно вторгається в сферу кримінально-процесуальних відносин, з іншого боку, має місце непослідовність кримінально-процесуального регулювання. Законодавець, хоча і в завуальованому вигляді, підтверджує, що результати ОРД, якщо вони відповідають вимогам, що пред'являються законом до доказів, можуть бути використані в процесі доказування, тобто $є$ допустимими доказами.

Натепер більшість вчених пропонує розглядати діяльність провокатора у рамках інституту співучасті, судова практика відбувається у аналогічному руслі та розглядає такі випадки як спеціальний вид підбурювання до вчинення відповідного злочину. Фактично, питання зводиться до меж виконання агентом злочинного завдання. Тут $є$ два аспекти: оперативний і правовий. Агент за жодних обставин не може бути організатором злочинної групи чи підбурювачем ії створення. За співучасть у злочинах, вчинюваних групою, 
він не нестиме кримінальну відповідальність згідно зі ст. 43 КК України, а отримані ним докази будуть допустимими. Якщо ж агент вчиняв провокацію з метою заслужити довіру членів наявної злочинної групи та стати ii учасником, без наміру використати здобуті внаслідок провокації докази для обвинувачення конкретних осіб у конкретному епізоді, то такі його дії не можуть кваліфікуватися за ст. 370 КК України [31, с. 72; 32].

При цьому поведінка особи в певних умовах визначається іï внутрішніми переконаннями і зовнішніми умовами. Отже, і їі реакція може бути не тільки і не стільки проявом вже сформованих намірів, скільки відповіддю на штучно створені умови. А чітко розмежувати штучне створення умов, що мають сприяти прояву існуючих намірів об'єкта та створення умов, що, власне, сприяють формуванню таких намірів та їх реалізації, практично неможливо [33].

О. Альошина взагалі порушує питання про можливість виключення відповідної норми як такої, що не $\epsilon$ достатнім кримінально-правовим засобом протидії провокаційній діяльності з боку службових осіб, та доповнити розділ XVIII Особливої частини КК України «Злочини проти правосуддя» статтею «Провокація злочину службовою особою правоохоронних органів». Можна погодитися і з думкою А. Минькової, що під час провокації злочинів у провокатора відсутній прямий умисел на вчинення злочину, його вчинення виконавцем виступає проміжним результатом досягнення іншої мети [30, с. $11-12,14 ; 3$, с. $83 ; 34$, с. 82-86].

Провокацію злочину слід відрізняти від провокуючої поведінки, яка в кримінологічному аспекті розглядається як обставина, що породжує причини і умови вчинення злочину. Це ж стосується і підбурювання до злочину, адже ї юридична природа не $\epsilon$ тотожною. Зазначимо, що юридична характеристика діяльності підбурювача випливає зі змісту ч. 4 ст. 27 КК України: «...особа, яка умовлянням, підкупом, погрозою, примусом або іншим чином схилила співучасника до вчинення злочину». Для підбурювання завжди притаманний двосторонній суб'єктивний зв'язок між особами, а під час провокації він може бути відсутнім. Тож провокатор може діяти таємно, шляхом створення умов і обставин, які зумовлюватимуть викриття спровокованої особи. Отже, провокація єширшим поняттям, ніжпідбурювання. Для провокації обов'язковою суб'єктивною ознакою $\epsilon$ спеціальна мета (викриття спровокованої особи), яка відсутня у разі підбурювання до вчинення злочину [29].

Висновки. Вищевикладене дозволяє дійти висновку про наявність прогалин у кримінальному, оперативно-розшуковому та кримінально-процесуальному законодавстві. Передусім дискусійним залишається питання декриміналізації діяння, чи, натомість, розширення застосування діючої правової норми, межі спонукання до злочину, відповідь на яке дасть змогу вдосконалення наявногоправового арсеналуправоохоронної діяльності.

\section{Література}

1. Назаров А.Д. Провокация в оперативно-розыскной деятельности. Москва : Юрлитинформ, 2010. 152 с.

2. Погорецький М.А. Застосування провокації в ході негласних розслідувань. Вісник кримінального судочинства. 2016. № 1. С. 33-43.

3. Иванов Андрей. Контрразведка в российском общественном мнении (1914-1917). Свободная мысль. 2008. № 2 (1585). С. 155-166.
4. Ольшевський Костянтин, Дирман Володимир. Принципи конфіденційного співробітництва. Юридичний часопис Національної академії внутрішніх справ. 2010. № 4 (16). С. 128-135.

5. Баглай І.П. Правове регулювання оперативно-розшукової діяльності в установах виконання покарань. Вісник Луганського державного університету внутрішніх справ імені Е.О. Дідоренка. 2011. № 1. С. 249-256.

6. Колодкин Л. Я умру, когда яд дойдет до сердца. Человек и закон. 1993. № 8. С. 76-88.

7. Хейфец И.Я. Подстрекательство к преступлению. Москва, 1914. 128 с.

8. Липранди И.П. О взятках, взяточниках и доносчиках. Чтения в Императорском обществе истории и древностей Российских при Московском университете. 1870. Кн. 3. С. $1-29$.

9. Бернадський Б.В. Контррозвідувальна діяльність Російської імперії в Україні (історико-правовий аспект). Київ : Видавець Карпенко В.М., 2018. 792 с.

10. Палеолог М. Царская Россия накануне революции. Москва : Политиздат, 1991. 493 с.

11. Кримінальний процесуальний кодекс України : від 13.04.2012 № 4651-VI. URL: http://zakon0.rada.gov.ua/ laws/show/ 4651-17.

12. Баганець О.В. Провокування підкупу: справи, про які мовчать. URL: https://protocol.ua/ua/provokuvannya_ pidkupu_spravi_pro_yaki_movchat/.

13. Регеза М. І. Особливості кваліфікації провокації підкупу. URL: https://naub.oa.edu.ua/2015/\%D0\%BE\%D1\% 81\%D0\%BE\%D0\%B1\%D0\%BB\%D0\%B8\%D0\%B2\%D0\%BE\%D1\% 81\%D1\%82\%D1\%96-\%D0\%BA\%D0\%B2\%D0\%B0\%D0\%BB\%D1\%96\% D1\%84\%D1\%96\%D0\%BA\%D0\%B0\%D1\%86\%D1\%96\%D1\%97-\%D0\% BF\%D1\%80\%D0\%BE\%D0\%B2\%D0\%BE\%D0\%BA\%D0\%B0\%D1\%86\% D1\%96\%D1\%97/.

14. Висновок на проект Закону України «Про внесення змін до деяких законодавчих актів України (щодо декриміналізації провокаціїхабара)» (реєстр. № 2754 від 10.07. 2008р.):

15. Порошенко хоче перемогти хабарі серед чиновників за допомогою таємних «агентів». URL: https: / / www.unian.ua/politics / 1085362-poroshenkohoche-peremogti-habari-sered-chinovnikiv-za-dopomogoyutaemnih-agentiv.html.

16. Батчаєв Володимир. Провокація на отримання хабара: отрута чи щеплення від корупції? URL: http: //cripo.com.ua/likbez/?p=242284/.

17. Постанова Кабінету міністрів України № 265 від 29 квітня 2015 р. «Про затвердження Державної програми щодо реалізації засад державної антикорупційної політики в Україні (Антикорупційної стратегіï) на 2015-2017 роки. URL: http: / /zakon2.rada.gov.ua/laws/show/265-2015-\%D0\%BF.

18. Закон України «Про засади державної антикорупційної політики в Україні (Антикорупційна стратегія) на 2014-2017роки».URL:http://zakon3.rada.gov.ua/laws/show/ 1699-18.

19. Роз'яснення щодо зриву спецоперації з викриття корупції в Державній міграційній службі України. URL: https://nabu.gov.ua/en/file/rozyasnennya-shchodo-zrivuspecoperaciyi-z-vikrittya-korupciyi-v-derzhavniy-migraciyniy-0.

20. Сапожнікова Олена. Провокація до вчинення злочину з боку працівників міліції. Інформаційний дайджест системи безоплатної правової допомоги в Україні. 2015. № 8. травень.

21. Томин С.В. Особливості застосування оперативної закупки як засобу отримання інформації про злочини, пов'язані зі збутом наркотичних засобів. Актуальні проблеми держави і права. 2011. Вип.60. С. 253-259.

22. Ухвала Апеляційного суду Вінницької області № 152/1444/14-K від 02.02.2015 p. URL: https://verdictum.ligazakon.net/document/42568918. 

досудового слідства

23. Виправдувальний вирок (провокування вчинення злочину). Провадження 607/18244/14-ку. URL: https://www.legalaid.gov.ua/publikatsiyi/vypravduvalnyjvyrok-provokuvannya-do-vchynennya-zlochynu/.

24. Сервецький І.В. Науково-практичний коментар Закону України «Про оперативно-розшукову діяльність» / І.В. Сервецький, В.А. Дашко. Київ, 2006. 400 с.

25. Основы оперативно-розыскной деятельности в Украине (понятие, принципы, правовое обеспечение) / Под ред. проф. Э. В. Виленской. Луганск : РИО ЛАВД, 2006. 245 с.

26. Моцний Д.О., Давиденко С.В. Провокація вчинення злочину при проведенні негласних слідчих (розшукових) дій у контексті захисту прав людини. Forum Prava. 2018. № 2. C. 90-97.

27. Карпушин М.П. Некоторые вопросы использования институтов общей части советского уголовного права в оперативно-следственной практике. Москва : ВШ КГБ CCCP, 1965. 112 C.

28. Корніенко М.В. Правові гарантії дотримання прав людини при проведенні оперативно-технічних заходів. Науковий вісник НАВС України. 2005. № 3. С. 125-132.

29. Бублик Ю.В. Пояснювальна записка до проекту Закону України «Про внесення змін до Кримінального кодексу України щодо встановлення відповідальності за провокацію злочину». URL: http://search.ligazakon.ua/ l_doc2.nsf/link1/GH3UV00A.html.
30. Альошина О.І. Провокація злочину (кримінально-правове дослідження) : автореф. дис. ... канд. юрид. наук : спец. 12.00.08. Дніпропетровськ, 2007. 19 с.

31. Фріс П.Л. Кримінально-правова відповідальність за провокацію злочинів (постановка питання). Haше право. 2008. № 1. С. 71-73.

32. Спільний наказ ГПУ, МВС, СБУ, ДПСУ, МФУ, Мінюсту України № 114/1042/516/1199/936/1687/5 від 16.11.2012 р. «Про затвердження Інструкції про організацію проведення негласних слідчих (розшукових) дій та використання їх результатів у кримінальному провадженні». URL: http://zakon.rada.gov.ua/laws/show/v0114900-12.

33. Новицький Григорій. Де закінчується агентурна операція i починається провокація? URL: http: / / mediarnbo.org/2017/07/19/de-zakinchuyetsyaagenturna-operatsiya-i-pochinayetsya-provokatsiya/.

34. Минькова А.М. Провокация преступлений: вопросы уголовно-правовой оценки. Кримінальний кодекс України 2001 р.: проблеми застосування і перспективи удосконалення: Матеріали міжнародної науково-практичної конференції 13-15 квітня 2007 р. Львів : Львівський державний університет внутрішніх справ 2007. С. 82-86.

Папуша I. 0. кандидат юридичних наук, доцент кафедри гуманітарних та соціально-економічних дисциплін Військової академії 